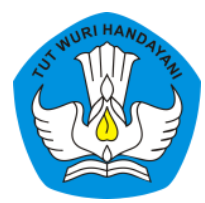

Page: 281-300

\title{
Peningkatan Kemampuan Menemukan Rumus Perbandingan Pembelajaran Matematika Siswa Kelas V Sekolah Dasar Berbantuan Media Perstupin
}

\author{
Yeni Fitri \\ Sekolah Dasar Negeri 03 Kampung Jawa, Kota Solok, Sumatera Barat \\ Contributor Email: yenifitri84dhirgan@gmail.com
}

Published: Juli 30, 2020

Article Url: https:/ / ojsdikdas.kemdikbud.go.id/index.php/didaktika/article/view/139

\begin{abstract}
The PERSTUPIN media is one of the teaching aids that can help students determine their own formula in solving everyday problems involving a comparison with known values. Learning by using PERSTUPIN media has been proved effective and successful. This can be seen from the results of the process assessment and the students' exercises individual assessment. The research method used is development research. The results showed that the use of PERSTUPIN media could improve students 'ability to find formulas, improve students' skills and learning outcomes. The Data obtained from the results of the process assessment showed that 20 students $(83.33 \%)$ got an $A$ and 4 students $(16.67 \%)$ got a B score. The improvement in the quality of the learning process gave positive impact on the improvement the quality of learning achievement. This is based on the average of student assessment, that is 94. Meanwhile, the number of students'who got learning completeness above the KKM was 100\% (24 students). Based on these data, it can be concluded media PERSTUPIN has been proved effective and successfulin improving the students' ability to find a comparison formula.
\end{abstract}

Keywords: Media PERSTUPIN, Comparison Formulas, Mathematics. 


\begin{abstract}
Abstrak
Media PERSTUPIN merupakan salah satu alat peraga yang dapat membantu siswa memenukan rumusnya sendiri dalam menyelesaikan masalah sehari-hari yang melibatkan perbandingan dengan nilai diketahui. Pembelajaran menggunakan media PERSTUPIN ini terbukti efektif dan berhasil. Hal ini dilihat dari hasil penilaian proses dan penilaian latihan individu siswa. Metode penelitian yang digunakan adalah penelitian pengembangan. Hasil penelitian menunjukkan bahwa penggunaan media PERSTUPIN dapat meningkatkan kemampuan siswa menemukan rumus, meningkatkan keterampilan dan hasil belajar siswa. Data yang didapat dari hasil penilaian proses, sebanyak 20 orang siswa (83,33\%) mendapat nilai A dan 4 orang siswa $(16,67 \%)$ mendapat nilai B. Peningkatan kualitas proses pembelajaran berdampak positif pada peningkatan kualitas prestasi belajar. Hal ini berdasarkan pada rata-rata penilaian siswa sebesar 94. Sedangkan ketuntasan belajar siswa di atas nilai KKM sebesar $100 \%$ (24 siswa). Berdasarkan data tersebut, dapat disimpulkan bahwa pembelajaran matematika dalam meningkatkan kemampuan menemukan rumus perbandingan menggunakan media PERSTUPIN telah mengalami peningkatan dan berhasil.
\end{abstract}

Keywords: Media PERSTUPIN, Rumus Perbandingan, Matematika.

\title{
A. Pendahuluan
}

Tujuan Pendidikan Nasional yang dirumuskan dalam UndangUndang Nomor 20 Tahun 2003 adalah untuk mengembangkan potensi peserta didik agar menjadi manusia yang beriman dan bertakwa kepada Tuhan Yang Maha Esa, berakhlak mulia, sehat, berilmu, cakap, kreatif, mandiri, dan menjadi warga negara yang demokratis serta bertanggung jawab. Berdasarkan Permendikbud No 67 tahun 2013 dalam kerangka dasar dan struktur kurikulum Sekolah Dasar. Matematika merupakan salah satu mata pelajaran yang wajib di pelajari oleh siswa sekolah dasar. Proses pembelajaran matematika di sekolah diharapkan dapat berjalan dengan efektif dan efisien.

Proses pembelajaran yang menarik dan menyenangkan akan membuat siswa betah dan mudah memahami materi pelajaran tersebut. Apalagi dengan bantuan media pembelajaran yang menarik siswa akan lebih bersemangat dan termotivasi dalam belajar dan siswa juga akan terbantu dalam memahami materi pelajaran tersebut. Sesuai dengan Peraturan 
Pemerintah Nomor 32 Tahun 2013 Pasal 19 ayat 1 tentang Standar Nasional Pendidikan dinyatakan bahwa "Proses Pembelajaran pada satuan pendidikan diselenggarakan secara interaktif, inspiratif, menyenangkan, menantang, memotivasi peserta didik untuk berpartisipasi aktif dan kreatif dalam mengembangkan minat, bakat, dan perkembangan fisik serta psikologisnya". Pembelajaran yang efektif, aktif dan kreatif akan membantu siswa dalam memahami ilmu pengetahuan dari beberapa mata pelajaran yang diajarkan.

Permasalahan yang sering ditemukan saat pembelajaran matematika di sekolah dasar,sebagian besar siswa menganggap pelajaran matematika merupakan pelajaran yang sulit, menakutkan, dan membosankan. Hal ini disebabkan karena proses pembelajaran matematika di kelas kurang menarik dan interaktif. Sehingga sebelum kegiatan pembelajaran dimulai siswa sudah menyerah dan merasa tidak akan mampu menguasai materi pelajaran yang akan disampaikan. Siswa tidak termotivasi untuk memahami materi pelajaran tersebut karena tidak fokus dan tidak berpartisipasi aktif dalam kegiatan pembelajaran. Hal ini mengakibatkan proses pembelajaran tidak berjalan dengan baik.

Berdasarkan hasil pengamatan, beberapa permasalahan tersebut juga terjadi dalam kegiatan pembelajaran siswa kelas V.C SDN 03 Kampung Jawa. Kendala utama yang ditemukan adalah kurangnya minat dan kemampuan siswa dalam memahami rumus-rumus pelajaran matematika yang diberikan. Siswa sering melakukan kesalahan dalam menulis dan menggunakan rumus materi pelajaran matematika terutama pada materi perbandingan. Salah satu cara yang dapat menarik perhatian dan motivasi siswa adalah dengan menggunakan media/alat peraga.

Alat peraga dapat membantu guru untuk mengubah paradigma yang selama ini berkembang pada masyarakat pada umumnya dan siswa khususnya. Dengan menggunakan alat peraga dalam pembelajaran matematika, materi matematika yang abstrak dapat disajikan kedalam pendekatan yang lebih konkret, ada visualisasinya, dan dapat menjadikan siswa lebih aktif dan kreatif dalam belajar sehingga materi yang ia pelajari 
dapat dimanfaatkan dalam kehidupan sehari-hari. Menurut Murwani (1999), untuk membelajarkan matematika secara benar pada siswa mutlak harus menggunakan alat peraga untuk memudahkan siswa mengenal konsep konsep matematika.

Sesuai dengan isi Peraturan Pemerintah Nomor 19 Tahun 2005, tentang Standar Pendidikan Nasional, Pasal 19 Ayat 1, yaitu "Kegiatan pembelajaran pada satuan pendidikan diselenggarakan interaktif, inspiratif, menyenangkan, menantang, memotivasi siswa untuk berperan aktif, kreatif dan mandiri sesuai dengan bakat, minat dan perkembangan fisik siswa." Sebagai seorang guru yang mengajarkan pelajaran matematika, saya berusaha mencari cara yang efektif dalam menjelaskan materi pada mata pelajaran matematika khususnya memecahkan masalah yang melibatkan perbandingan. Mulai dari membuat gambar sampai menggunakan media atau alat peraga agar membantu siswa dalam memahami materi tersebut.

Berdasarkan uraian tersebut, agar siswa dapat menyelsaian soal cerita yang melibatkan perbandingan diperlukan peranan media pembelajaran yang efektif. Media tersebut diberi nama PERSTUPIN (Perbandingan Stick Upin dan Ipin). Dengan menggunakan tokoh dan karakter salah satu kartun terkenal di kalangan anak-anak saat ini, penulis berharap siswa akan lebih tertarik dan bersemangat dalam belajar. Tujuannya agar dapat membantu siswa dalam memahami soal dan menemukan rumus menyelesaian masalah sehari-hari yang melibatkan perbandingan. Berdasarkan latar belakang tersebut, rumusan masalah dalam karya inovasi ini adalah sebagai berikut : 1) Apakah media PERSTUPIN (Perbandingan Stick Upin dan Ipin) dapat meningkatkan keterampilan siswa dalam menyelesaikan permasalahan sehari-hari yang melibatkan perbandingan dengan nilai yang diketahui ?; 2) Apakah media PERSTUPIN (Perbandingan Stick Upin dan Ipin) dapat membantu siswa menemukan rumus perbandingan dalam memecahkan permasalahan sehari-hari?; 3) Bagaimanakah peningkatan hasil belajar siswa pada materi perbandingan 
dengan nilai yang diketahuisetelah dilakukan pembelajaran dengan menggunakan media PERSTUPIN (Perbandingan Stick Upin dan Ipin) ?

Adapun tujuan penelitian ini adalah untuk meningkatkan keterampilan siswa dalam menyelesaikan permasalahan sehari-hari yang melibatkan perbandingan dengan nilai yang diketahui, membantu siswa menemukan rumus perbandingan dalam memecahkan permasalahan sehari-hari dan meningkatkan hasil belajar siswa pada materi perbandingan dengan nilai yang diketahui.

Manfaat yang diharapkan dari penelitian ini adalah dapat meningkatkan kompetensi peneliti sebagai guru dalam bidang kompetensi profesional dan kompetensi pedagogik serta dapat meningkatkan keterampilan guru dalam membuat media pembelajaran yang inovatif. Manfaat bagi penelitian ini bagi siswa antara lain dapat meningkatkan kreativitas siswa memecahkan permasalah sehari-hari yang melibatkan perbandingan serta dapat meningkatkan motivasi dan nilai matematika siswa pada materi perbandingan. Adapun manfaat penelitian ini bagi sekolah adalah untuk menambah pengetahuan para guru mengenai perancangan dan pemanfaatan media pembelajaran saat mengajar di kelas serta memberikan kontribusi karya bagi sekolah dalam rangka pengembangan dan penyempurnaan karya inovatif ini selanjutnya.

\section{B. Metode}

Metode yang digunakan dalam penelitian ini adalah metode penelitian pengembangan yang mengacu pada model penelitian pengembangan 4-D oleh Thiagarajan, dkk (1974:5). Model 4-D terdiri atas empat tahap pengembangan yaitu define (pendefinisian), design (perancangan), develop (pengembangan), dan disseminate (penyebarluasan). Pada tahap define, peneliti menganalisis kebutuhan dan permasalahan yang terjadi saat pembelajaran materi perbandingan yaitu dalam memecahkan masalah sehari-hari yang melibatkan perbandingan. Kemudian peneliti menganalisis karakteristik peserta didik, dan konsep materi perbandingan. Tahap kedua yaitu design, peneliti merancang media pembelajaran yang 
dapat membantu peserta didik dalam menyelesaikan permasalahan seharihari yang melibatkan perbandingan dengan bahan utamanya berupa Stik es dan gelas plastik bekas. Media ini juga dapat membantu peserta didik menemukan sendiri rumus perbandingan dengan mengikuti langkahlangkah pada LKS. Tahap ketiga yaitu develop, peneliti membuat media yang diberi nama PERSTUPIN dan diujicobakan pada siswa kelas V.C SDN 03 Kampung Jawa Kota Solok. Tahap keempat yaitu disseminate, media ini didiseminasikan pada majelis guru dan kepala sekolah serta para guru kelas V.C Kota Solok saat kegiatan KKG. Instrumen pengumpulan data yang digunakan adalah angket, rubrik penilaian proses dan penilaian pengetahuan. Teknik analisis data yang digunakan adalah teknik kuatitatif.

\section{Hasil dan Pembahasan}

Dalam matematika, materi perbandingan dan aplikasinya bisa merupakan upaya membandingkan dua objek atau lebih, lalu menghitungnya dengan rumus yang tepat. Pengertian perbandingan/rasio yaitu sebuah ekspresi matematika yang membandingkan dua angka atau lebih. Dalam hal ini bisa digunakan untuk membandingkan beberapa angka untuk menunjukkan porsi tertentu dari jumlah keseluruhan. Soal perbandingan yang sering kita temui dalam pembelajaran matematika biasanya adalah perbandingan umur, banyak benda, tinggi badan, berat badan dan nilai mata pelajaran. Pada prinsipnya perbandingan terbagi atas dua jenis, yaitu perbandingan senilai (nilainya tetap atau sama) dan perbandingan berbalik nilai (nilainya tetap, walaupun terbalik).

Salah satu kelebihan materi perbandingan adalah memiliki konsep yang dapat diaplikasikan dalam kehidupan sehari-hari. Seperti untuk menentukan umur seseorang jika diketahui perbandingan, jumlah atau selisih suatu benda, menakar bahan-bahan yang digunakan untuk memasak, menentukan jarak dari kota A ke kota B. 
Media PERSTUPIN ini dirancang untuk menyelesaikan masalah sehari-hari yang melibatkan perbandingan untuk nilai yang diketahui. Contoh soal pada materi ini antara lain: (1) Jika diketahui jumlah dan perbandingan A : B. Contoh soalnya yaitu diketahui perbandingan umur kakak dan umur adik 4:5. Jika jumlah umur kakak dan adik 36 tahun. Berapa umur kakak dan umur adik?; (2) Jika diketahui selisih dan perbandingan A : B. Contoh soalnya yaitu diketahui perbandingan umur Ayah dan umur Ibu 5:7. Jika selisih umur ayah dan umur ibu 12 tahun. Berapa umur ayah dan umur ibu?; (3) Jika diketahui nilai salah satu perbandingan. Contoh soalnya yaitu diketahui perbandingan banyak ayam dan itik di sebuah peternakan adalah $5: 8$. Jika banyak itik 32 ekor. Tentukalah : (a) Banyak ayam pada peternakan tersebut; (b) jumlah ayam dan itik; (c) selisih ayam dan itik. Soal-soal perbandingan seperti di atas sangat sering dijumpai pada materi pelajaran Matematika kelas V. Oleh sebab itu, guru perlu mencari cara yang efektif untuk membantu siswa memahami dan menyelesaikan permasalahan tersebut dengan cara yang mudah dan menyenangkan.

Ide dasar dari pembuatan media PERSTUPIN ini berawal dari pengalaman mengajarkan materi perbandingan. Biasanya guru memberikan dan mengajarkan beberapa rumus untuk menyelesaikan berbagai model soal cerita, namun banyak siswa yeng tidak dapat memahami dan menghafalkan rumus tersebut karena masih bersifat abstrak. Untuk memudahkan siswa memahami masalah perbandingan tersebut, awalnya guru mencoba menjelaskan konsep perbandingan tersebut dengan menggunakan gambar-gambar dan simbol. Sebagian siswa mulai mengerti dan memahami cara menyelesaikan permasalahan yang melibatkan perbandingan. Namun, guru merasa belum puas karena kegiatan pembelajaran dirasa kurang menarik.

Setelah itu, muncul ide dan pemikiran untuk menjadikan gambar dan simbol yang digunakan tadi ke dalam bentuk yang lebih nyata yaitu dengan membuat media konkret yang dirancang untuk membantu siswa dalam menyelesaikan masalah sehari-hari yang melibatkan perbandingan. 
Berdasarkan hasil penelitian Sukarni, Hery Kresnadi, Mastar Asran Tahun 2015 (Vol 4. No. 12 (2015) menunjukkan bahwa pembelajaran matematika menggunakan media konkret mengalami peningkatan pada setiap siklus. Untuk menarik perhatian dan minat siswa penulis memberi tema Upin dan Ipin karena hampir setiap hari menyaksikan siswa mengisi waktu istirahatnya dengan permainan Stik Upin dan Ipin. Diharapkan dengan menggunakan media pembelajaran ini, siswa mendapatkan pengalaman belajar yang menyenangkan dalam menyelesaikan permasalahan seharihari yang melibatkan perbandingan dan dapat menemukan cara dan rumus sendiri dalam menyelesaikan soal-soal tersebut.

Media PERSTUPIN (Perbandingan Stik Upin dan Ipin) merupakan alat bantu yang dibuat untuk membantu siswa dalam menyelesaikan permasalahan sehari-hari yang melibatkan perbandingan. Hal ini sesuai dengan pendapat Syaiful Bahri Djamarah dan Azwan Zain (210:121) yang menjelaskan bahwa media pembelajaran merupakan alat bantu yang dapat dijadikan sebagai penyalur pesan untuk mencapai tujuan pembelajaran. Berikut rancangan karya inovasi media PERSTUPIN sebagai berikut:

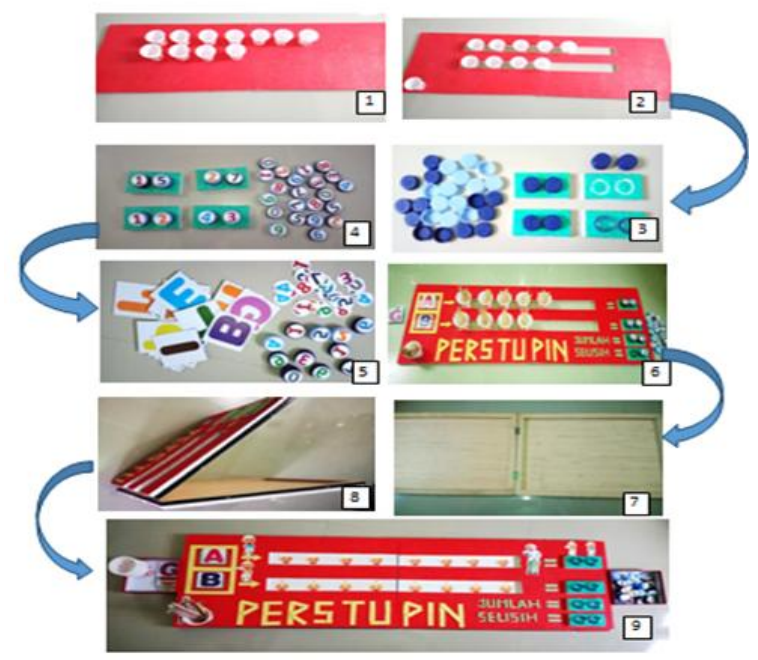

Gambar 1. Rancangan Pembuatan Media PERSTUPIN 
Dengan menggunakan media tersebut siswa dapat menemukan cara dan rumus yang mereka temukan sendiri dengan mengikuti panduan dan langkah-langkah pada lembar kerja siswa (LKS). Jenis inovasi yang diciptakan adalah media pembelajaran yang interaktif. Dengan adanya Stik Upin dan Ipin mereka tidak akan merasa terbebani dalam menyelesaikan berbagai persoalan yang diberikan, bahkan mereka asyik menggunakan media tersebut seperti asyiknya bermain di saat jam istirahat. Semua siswa dalam kelompok dapat ikut aktif karena adanya beberapa langkah yang dapat mereka kerjakan secara bersama-sama.

Dengan menggunakan media tersebut siswa dapat menemukan cara dan rumus yang mereka temukan sendiri dengan mengikuti panduan dan langkah-langkah pada lembar kerja siswa (LKS). Jenis inovasi yang diciptakan adalah media pembelajaran yang interaktif. Dengan adanya Stik Upin dan Ipin mereka tidak akan merasa terbebani dalam menyelesaikan berbagai persoalan yang diberikan, bahkan mereka asyik menggunakan media tersebut seperti asyiknya bermain di saat jam istirahat. Semua siswa dalam kelompok dapat ikut aktif karena adanya beberapa langkah yang dapat mereka kerjakan secara bersama-sama.

Berikut contoh penggunaan media PERSTUPIN jika diketahui jumlah dan angka perbandingan. Jumlah umur Andi dengan umur Bima 27 tahun. Jika perbandingan umur Andi dengan umur Bima 5 : 4 maka tentukanlah : (a) Umur Andi?; (b)Umur Bima?; (c) Selisih umur Andi dan Bima?

Langkah-langkah :

1. Pasangkan kartu inisial nama Andi dan Bima pada tempat yang sudah disediakan

2. Letakkan gelas sebanyak angka perbandingan pada soal tersebut yaitu 5 untuk Andi dan 4 untuk Bima.

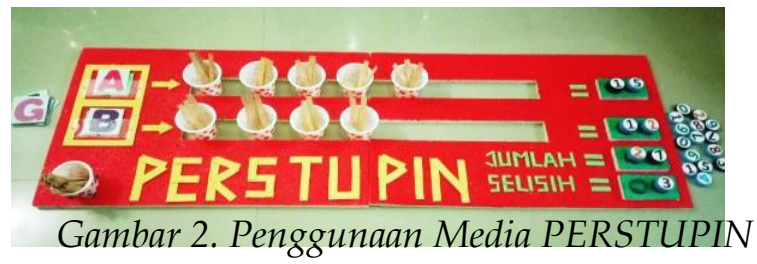


3. Ambil stik sebanyak 27 buah dan masukkan ke dalam gelas sama banyak.

4. Hitunglah banyak stik pada setiap gelas kemudian hitung jumlah stik Andi dan jumlah stik Bima

5. Jumlah Stik Andi merupakan umur Andi dan jumlah Stik Bima merupakan umur Bima. Untuk mencari selisih umur mereka kita dapat melihat selisih stik ada gelas atau mengurangkan jumlah Stik Andi dengan stik Bima.

Kemudian siswa dipandu menemukan rumus perbandingan berdasarkan langkah kerja tersebut. (LKS terlampir)

6. Cara menemukan rumus :

Lengkapi operasi bilangan berikut sesuai langkah-langkah yang kamu kerjakan :

Umur Andi $=\frac{\mathrm{m} 27_{\operatorname{mm}}}{\mathrm{m} m 5+4 \mathrm{mmm}} x \ldots 5 \ldots=15$

Umur Bima $=\frac{\mathrm{m} 27_{\operatorname{mm}}}{\mathrm{mm} 5+4 \mathrm{mmm}} x \ldots 4 \ldots=12$

Jika, perbandingan umur Andi disimbolkan dengan "A"dan perbandingan umur Bima disimbolkan dengan "B". Jumlah umur mereka disimbolkan dengan "Jumlah", maka rumusnya adalah :

Umur Andi $=\frac{\text { mJumlah.mm }}{\operatorname{ma} A+B_{\operatorname{mam}}} x \ldots A \ldots$

Umur Bima $=\frac{\text { Jumlah.mm }}{\operatorname{mm} A+B_{\operatorname{mm} m}} x \ldots B \ldots$

Berikut data isian hasil kuisioner siswa setelah melaksanakan proses pembelajaran menggunakan media PERSTUPIN. 


\section{Tabel 1. Hasil pengisian kuisioner siswa tentang penggunaan media PERSTUPIN (Perbandingan Stick Upin dan Ipin)}

Responden : : Siswa kelas V SD Negeri 03 Kampung Jawa Total responden $\quad: 24$ orang siswa

\begin{tabular}{|c|c|c|c|c|c|c|}
\hline \multirow[b]{2}{*}{ No } & \multirow[b]{2}{*}{ Pertanyaan } & \multicolumn{5}{|c|}{ Pilihan Jawaban } \\
\hline & & $\begin{array}{l}\text { Sangat } \\
\text { setuju } \\
\text { (Skor 4) }\end{array}$ & $\begin{array}{l}\text { Setuju } \\
\text { (Skor 3) }\end{array}$ & $\begin{array}{l}\text { Kurang } \\
\text { Setuju } \\
\text { (Skor 2) }\end{array}$ & $\begin{array}{l}\text { Tidak } \\
\text { Setuju } \\
\text { (Skor 1) }\end{array}$ & Skor \\
\hline 1. & $\begin{array}{l}\text { Media PERSTUPIN } \\
\text { sangat menarik bagi saya }\end{array}$ & 23 & 1 & - & - & 47 \\
\hline 2. & $\begin{array}{l}\text { Saya mengerti dan bisa } \\
\text { menggunakan media } \\
\text { PERSTUPIN }\end{array}$ & 22 & 2 & - & - & 46 \\
\hline 3. & $\begin{array}{l}\text { Media PERSTUPIN bisa } \\
\text { membantu saya } \\
\text { menyelesaikan soal cerita } \\
\text { tentang perbandingan }\end{array}$ & 22 & 2 & - & - & 45 \\
\hline 5. & $\begin{array}{lr}\text { Saya dapat menemukan } \\
\text { rumus } & \text { sendiri } \\
\text { menggunakan } & \text { media } \\
\text { PERSTUPIN } & \end{array}$ & 21 & 3 & - & - & 44 \\
\hline & Berdasarkan lembar & pengam & natan & proses & pembel & lajaran \\
\hline & $\begin{array}{l}\text { yelesaikan permasalahan s } \\
\text { ggunakan media PERSTU1 } \\
\text { at semua aspek penilaian } \\
\text { at baik. }\end{array}$ & $\begin{array}{l}\text { hari-hari } \\
\text { IN (Perb } \\
\text { aktivitas }\end{array}$ & $\begin{array}{l}\text { yang } m e \\
\text { pandingar } \\
\text { siswa te }\end{array}$ & $\begin{array}{l}\text { elibatkar } \\
\text { n Stik L } \\
\text { rmasuk }\end{array}$ & $\begin{array}{l}\text { perbanc } \\
\text { Jpin dan } \\
\text { dalam ka }\end{array}$ & $\begin{array}{r}\text { dingan } \\
\text { Ipin), } \\
\text { ategori }\end{array}$ \\
\hline
\end{tabular}

Tabel 2. Persentase Hasil Penilaian Proses

\begin{tabular}{cccc}
\hline Rentang Nilai & Predikat & Banyak Siswa (orang) & Persentase \\
\hline $92-100$ & A & 20 & $83,33 \%$ \\
$83-91$ & B & 4 & $16,67 \%$ \\
$75-82$ & - & - & - \\
\hline
\end{tabular}




\section{Skor :}

5 = Sangat Baik

4 = Baik

3 = Cukup

2 = Kurang

1 = Sangat Kurang

Adapun aspek yang dinilai dalam penilaian latihan menyelesaikan permasalahan sehari-hari yang melibatkan perbandingan menggunakan media PERSTUPIN (Perbandingan Stik Upin dan Ipin) adalah : 1) Ketepatan rumus; 2) Langkah penyelesaian masalah; 3) Hasil.

Tabel 3. Persentase Nilai Latihan Individu

\begin{tabular}{cccc}
\hline Rentang Nilai & Predikat & Banyak Siswa (orang) & Persentase \\
\hline $92-100$ & A & 20 & $83,34 \%$ \\
$83-91$ & B & 2 & $8,33 \%$ \\
$75-82$ & C & 2 & $8,33 \%$ \\
\hline
\end{tabular}

Dokumentasi Kegiatan Pembelajaran dengan menggunakan media PERSTUPIN (Perbandingan Stick Upin dan Ipin).

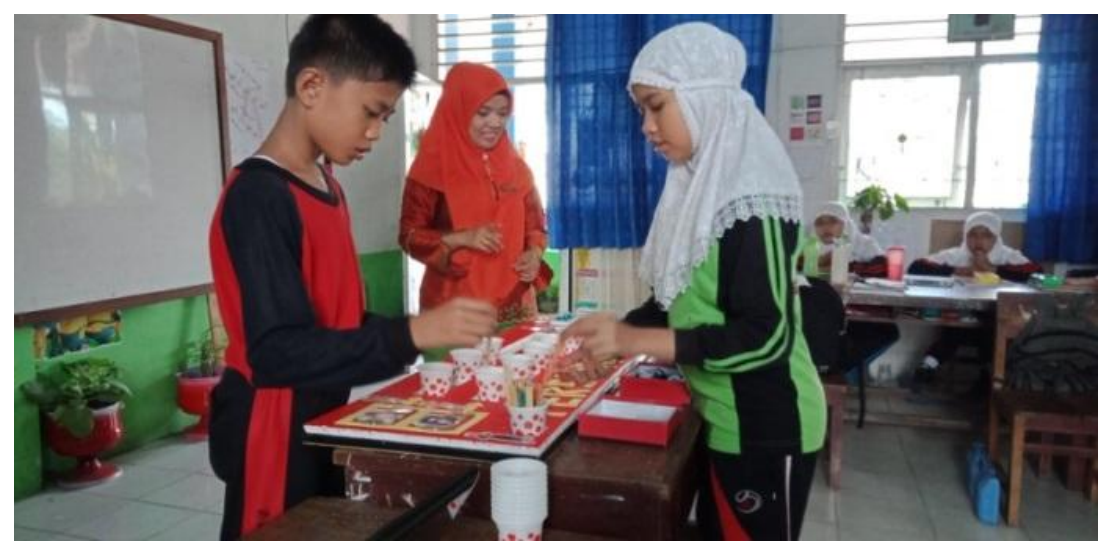

Gambar 3. Siswa mendemonstrasikan cara menggunakan media PERSTUPIN. 


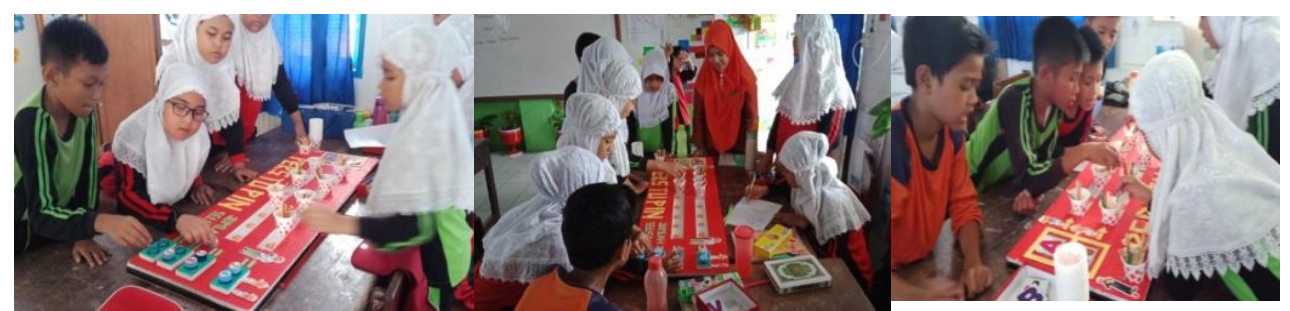

Gambar 4. Siswa menggunakan media PERSTUPIN dalam menyelesaikan masalah sehari-hari dengan panduan LKS.
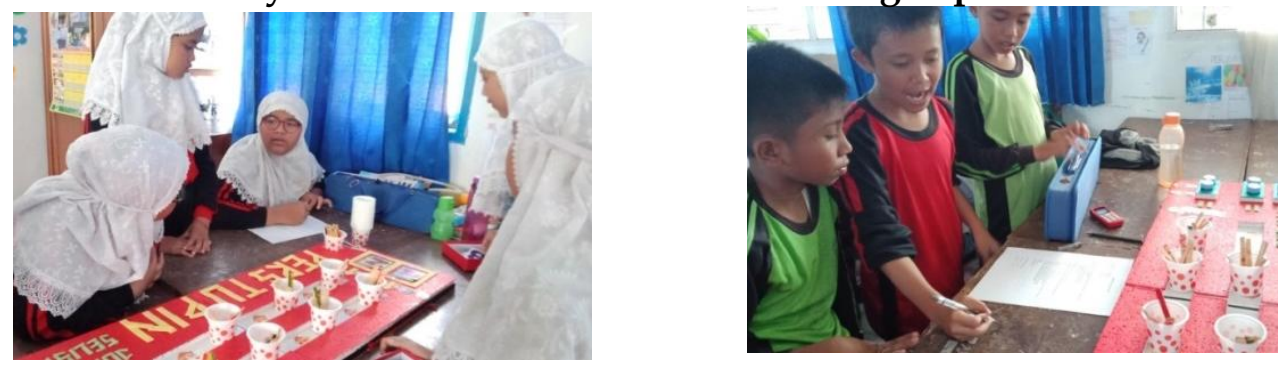

Gambar 5. Siswa berdiskusi mengisi LKS dan menemukan rumus penyelesaian soal perbandingan tersebut.

Berdasarkan data isian angket siswa, di bawah ini disajikan tabel dan grafik untuk mengetahui respon siswa setelah menggunakan media PERSTUPIN (Perbandingan Stick Upin dan Ipin).

Tabel 4. Persentase Pengisian Angket Siswa Setelah Menggunakan Media PERSTUPIN (Perbandingan Stick Upin dan Ipin)

Responden : : Siswa kelas V SD Negeri 03 Kampung Jawa

Total responden $\quad$ : 24 orang siswa

\begin{tabular}{|c|c|c|c|c|c|}
\hline \multirow[b]{2}{*}{ No } & \multirow[b]{2}{*}{ Pertanyaan } & \multicolumn{4}{|c|}{ Pilihan Jawaban } \\
\hline & & $\begin{array}{l}\text { Sangat } \\
\text { Setuju }\end{array}$ & Setuju & $\begin{array}{l}\text { Kurang } \\
\text { Setuju }\end{array}$ & $\begin{array}{l}\text { Tidak } \\
\text { Setuju }\end{array}$ \\
\hline 1. & $\begin{array}{l}\text { Media PERSTUPIN sangat menarik } \\
\text { bagi saya }\end{array}$ & $96 \%$ & $4 \%$ & $0 \%$ & $0 \%$ \\
\hline 2. & $\begin{array}{l}\text { Saya mengerti dan bisa } \\
\text { menggunakan media PERSTUPIN }\end{array}$ & $92 \%$ & $8 \%$ & $0 \%$ & $0 \%$ \\
\hline 3. & $\begin{array}{l}\text { Media PERSTUPIN bisa membantu } \\
\text { saya menyelesaikan soal cerita } \\
\text { tentang perbandingan }\end{array}$ & $92 \%$ & $8 \%$ & $0 \%$ & $0 \%$ \\
\hline 4. & $\begin{array}{ll}\text { Saya dapat menemukan rumus } & \text { rutia } \\
\text { sendiri menggunakan } & \text { media }\end{array}$ & $88 \%$ & $13 \%$ & $0 \%$ & $0 \%$ \\
\hline
\end{tabular}




\section{PERSTUPIN}

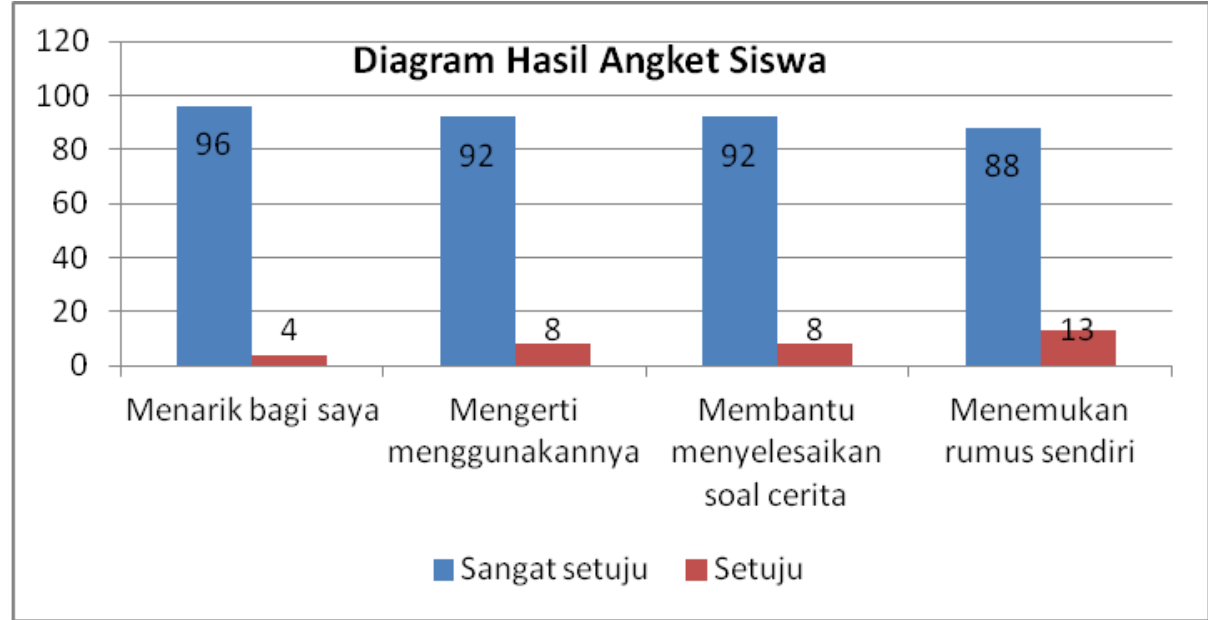

\section{Diagram 1. Hasil Angket Siswa Setelah Menggunakan Media PERSTUPIN}

Pada awal pembelajaran ketika guru pertama kali memperkenalkan media PERSTUPIN kepada siswa, mereka terlihat penasaran dan ingin tahu media apa ini, untuk apa, dan bagaimana cara menggunakan. Secara spontan mereka memuji media tersebut. Mereka berkata : "Bagus medianya buk ada gambar upin ipinnya lagi, warnanya juga cantik". Sesuai dengan diagram di atas dari 24 siswa kelas V.C ada 96\% siswa yang sangat tertarik menggunakan media PERSTUPIN dalam belajar. Saat guru menjelaskan tentang bagian-bagian media PERSTUPIN dan cara menggunakannya, para siswa terlihat antusias dan penuh perhatian karena mereka terlihat tidak sabar untuk menggunakannya.

Berdasarkan diagram di atas dapat disimpulkan bahwa sebagian besar siswa kelas V.C tertarik dan senang menggunakan media PERSTUPIN. Media tersebut dalam membantu menyelesaikan masalah yang melibatkan perbandingan sehingga mereka dapat menemukan rumusnya sendiri.

Penilaian proses juga dilaksanakan pada proses pembelajaran. Berikut merupakan hasil penilaian proses pembelajaran menggunakan media PERSTUPIN. 


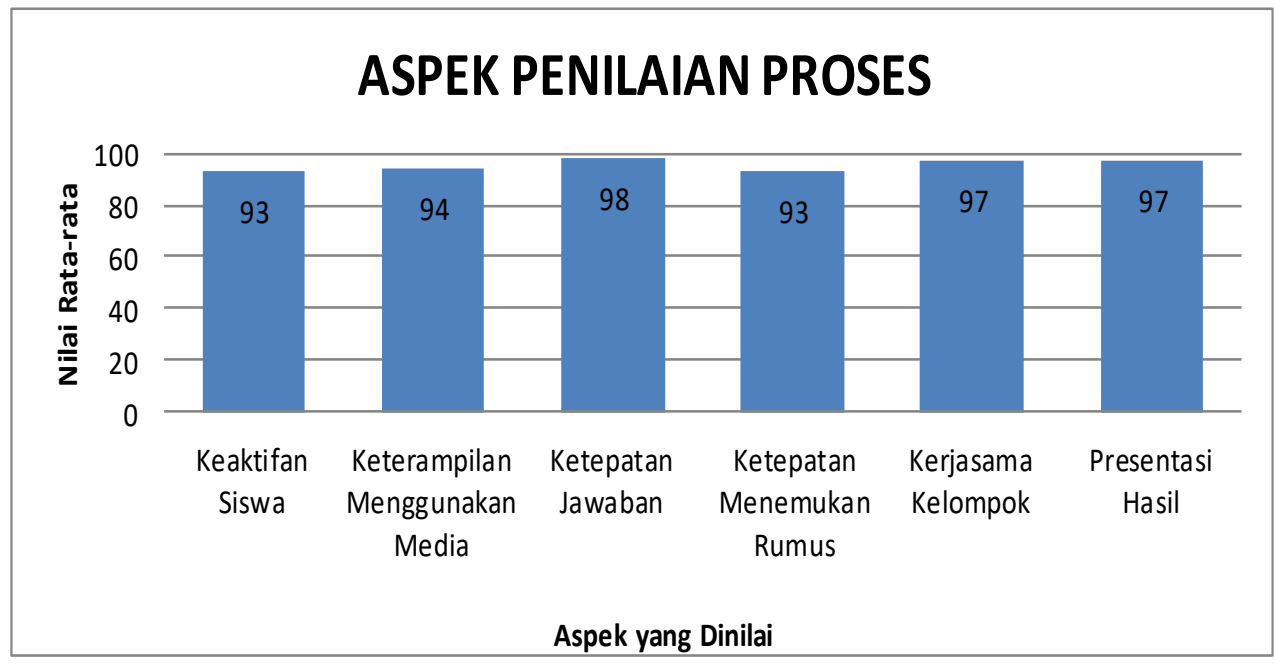

Berdasarkan diagram hasil penilaian proses tersebut, terlihat sebagian besar siswa aktif selama proses pembelajaran, semua anggota kelompok ikut serta dalam mencoba dan mempraktekkan penggunaan media PERSTUPIN dalam menyelesaikan soal pada LKS sesuai dengan langkah-langkah yang telah dipandu pada LKS tersebut. Dapat disimpulkan bahwa pembelajaran dengan menggunakan media PERSTUPIN dapat meningkatkan keterampilan dan keaktifan siswa dalam proses pembelajaran. Nilai rata-rata kelas untuk kegiatan ini sangat baik yaitu 95. Pembelajaran menjadi aktif, kreatif dan menyenangkan serta dapat menemukan rumus sendiri dengan bantuan media PERSTUPIN.

Selain penilaian proses, peneliti juga melakukan penilaian pengetahuan untuk melihat hasil belajar siswa. Berikut ini merupakan hasil penilaian latihan individu siswa setelah melaksanakan proses pembelajaran menggunakan media PERSTUPIN. 


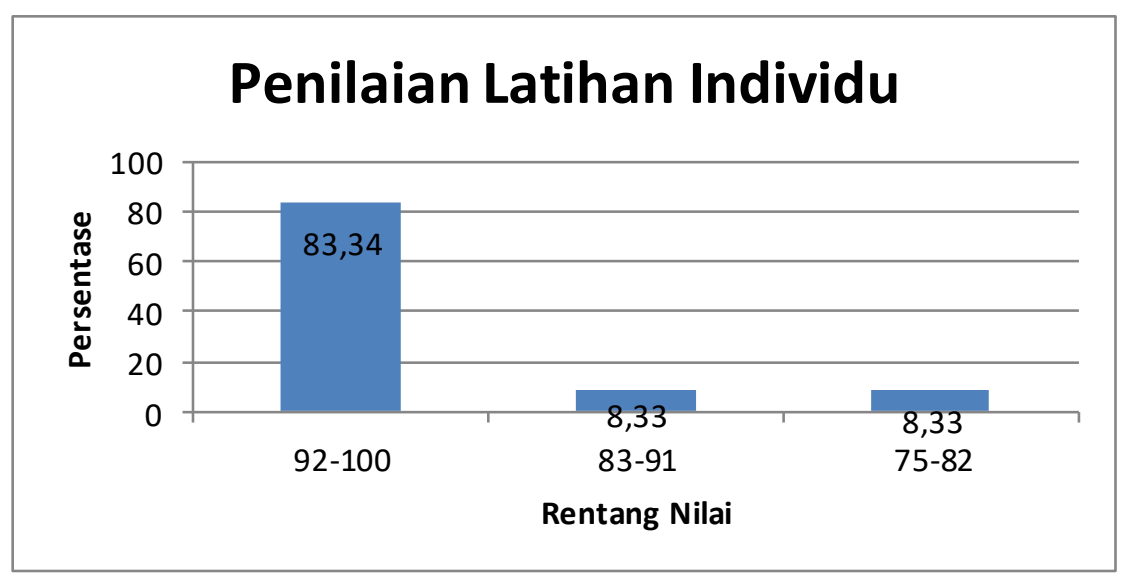

\section{Diagram 3. Hasil Penilaian Latihan Siswa Setelah Menggunakan Media PERSTUPIN}

Berdasarkan penelitian tersebut, dapat disimpulkan bahwa pembelajaran matematika dengan menggunakan media PERSTUPIN (Perbandingan Stik Upin dan Ipin dapat meningkatkan ketuntasan belajar siswa khususnya materi perbandingan dalam menyelesaikan permasalahan sehari-hari untuk nilai yang diketahui. ketuntasan belajar siswa secara klasikal mencapai 100\% dengan Kriteria Ketuntasan Minimal (KKM) 75.

Untuk kelayakan produk media PERSTUPIN dalam pembelajaran, penulis melakukan uji validasi dengan guru Matematika SMP Negeri 5 Kota Solok yang memiliki keahlian di bidang matematika dengan latar belakang pendidikan S.2 Matematika. Validasi diukur dari segi kesesuaian dan keefektifan produk yang diciptakan dalam mencapai tujuan pembelajaran. Selain itu juga dilakukan validasi terhadap instrumen penilaian, LKS, dan angket respon siswa. Hasil validasi menunjukkan bahwa media PERSTUPIN layak digunakan sebagai media pembelajaran untuk memecahkan permasalahan sehari-hari yang melibatkan perbandingan.

\section{Penutup}

Berdasarkan data dan pembahasan yang telah diperoleh selama proses pembelajaran dengan menggunakan Media PERSTUPIN (Perbandingan Stik Upin dan Ipin) dapat ditarik beberapa kesimpulan 
sebagai berikut : (1) penggunaan Media Media PERSTUPIN (Perbandingan Stik Upin dan Ipin) dapat meningkatkan keterampilan siswa dalam membuat memecahkan permasalahan sehari-hari yang melibatkan perbandingan dengan nilai yang diketahui. sehingga siswa lebih aktif, kreatif dan menyenangkan selama melaksanakan proses pembelajaran; (2) Penggunaan Media PERSTUPIN (Perbandingan Stik Upin dan Ipin) terbukti dapat membantu siswa menemukan rumus perbandingan dalam memecahkan permasalahan sehari-hari dengan persentase keberhasilan siswa 92\%; (3) Penggunaan Media Media PERSTUPIN (Perbandingan Stik Upin dan Ipin) juga dapat meningkatkan hasil belajar siswa pada materi perbandingan dengan nilai yang diketahui dengan nilai rata-rata kelas 94 (sangat baik). Setelah menggunakan media PERSTUPIN di kelas V.C diperoleh ketuntasan belajar siswa dapat mencapai $100 \%$.

Berdasarkan proses pembelajaran yang telah dilakukan menggunakan media PERSTUPIN (Perbandingan Stik Upin dan Ipin), penulis memberikan beberapa saran sebagai berikut : (1) Agar para guru dapat membuat dan menggunakan media PERSTUPIN sebagai salah satu upaya meningkatkan keterampilan dan hasil belajar siswa dalam menyelesaikan permasalahan sehari-hari yang melibatkan perbandingan; (2) Untuk memudahkan penggunaan media PERSTUPIN pada proses pembelajaran, sebaiknya dibuat dalam bentuk dua versi yaitu : versi horizontal dan versi vertikal. Versi horizontal yaitu sama halnya dengan yang penulis buat sekarang ini dimana media PERSTUPIN dipajang diatas meja untuk digunakan siswa secara berkelompok. Sedangkan versi vertikal maksudnya media yang dapat dipajang dengan cara digantung di depan kelas sehingga lebih jelas tampak oleh siswa saat guru menjelaskan cara penggunaannya. Perbedaannya terdapat pada letak gelas dengan menggunakan penggantung; (3) Media PERSTUPIN sebaiknya dibuat sebanyak jumlah kelompok, agar setiap kelompok lebih leluasa menggunakan media dengan efektif dan efisien. 


\section{Ucapan Terimakasih}

Penulisan karya ilmiah ini dapat selesai dengan dukungan dan bantuan dari beberapa pihak. Untuk itu, ucapan terima kasih penulis ucapkan pada keluarga, kepala sekolah, teman-teman guru dan dinas pendidikan Kota Solok. Penulis juga mengucapkan terima kasih kepada Direktur Direktorat Guru dan Tenaga Kependidikan, Kesharlindungdikdas dan editor jurnal Didaktika Pendidikan Dasar yang telah memberikan bimbingan dan fasilitas dalam penulisan dan penerbitan artikel ini.

\section{Daftar Referensi}

Abdurrahman, M. 2003. Pendidikan bagi anak berkesulitan belajar. Jakarta: Rineka Cipta.

Djamarah, Syaiful Bahri, dan Aswan Zain. 2002. Strategi Belajar Pembelajaran. Jakarat: PT Rineka Cipta.

Depdikbud (1993). Kurikulum Pendidikan Dasar: GBPP SLTP Mata Pelajaran Matematika. Jakatra: Depdikbud.

Depdiknas. 2003. Undang-undang RI nomor 20 tahun 2003. Tentang sistem pendidikan nasional.

Fujiati, I. (2014). Keefektifan Model Pogil Berbantuan Alat Peraga Berbasis Etnomatematika Terha $\neg$ dap Kemampuan Komunikasi Matematis. Unnes Journal of Mathematics Education, 3(3).

Hamdani. 2011. Strategi Belajar Mengajar, Bandung: Pustaka Setia.

Muhsetyo G., dkk. 2007. Pembelajaran Matematika SD. Jakarta: Universita Terbuka.

Musfiqon, HM. 2011. Pengembangan Media dan Sumber Pembelajaran, Jakarta: Prestasi Pustakaraya.

Parman, A. (2017) Peningkatan hasil belajar matematika pada pembelajaran perbandingan dan skala dengan menggunakan media roda puzzle untuk belajar (dazzle ujar) pada siswa kelas V Sd N suryodiningratan II. Diakses dari https:/ / eprints.uny.ac.id/49043/.

Peraturan Pemerintah Nomor 19 Tahun 2005. Standar pendidikan nasional. Jakarta: Depdiknas.

Permendikbud Nomor 15 tahun 2018 tentang pemenuhan beban kerja guru. 
Permendikbud No. 67 Tahun 2013Tentang Kerangka Dasar dan Struktur Kurikulum Sekolah Dasar/Madrasah Ibtidaiyah.

Siswanto, R., Sugiono, S., \& Prasojo, L. (2018). The Development of Management Model Program of Vocational School Teacher Partnership with Business World and Industry Word (DUDI). Jurnal Ilmiah Peuradeun, 6(3), 365-384. doi:10.26811/peuradeun.v6i3.322.

Sudjana, N. dkk. 2011. Media Pengajaran, Bandung: Sinar Baru Algensindo.

Suherman, E, dkk. 2003. Strategi pembelajaran matematika kontemporer.Bandung: PT Remaja Rosdakarya.

Sukarni, Kresnady H., \& Asran M. 2015. Penggunaan Media Konkret Dalam Pembelajaran Matematika Untuk Meningkatkan Hasil Belajar Siswa Di Sekolah Dasar. Diakses dari http://jurnal.untan.ac.id/index.php/jpdpb/article/view/12958.

Thiagarajan, S., Semmel, D. S \& Semmel, M. I. 1974. Instructional Development for Training Teachers of Expectional Children. Minneapolis, Minnesota: Leadership Training Institute/Special Education, University of Minnesota.

Umrotul K. 2013. Penggunaan media peta untuk memahamkan materi perbandingan melalui Pembelajaran kooperatif tipe grup investigasi pada siswa kelasVII-A SMP Negeri 2 Jetis Kabupaten Mojokerto. Diakses dari http://jurnalonline.um.ac.id/data/artikel/artikel589 EB8A55925DCC98880F6B72 D71F9D1.pdf. 
Vol. 4, No. 2, Juli 2020 